\title{
The forensic application of DNA barcoding for identification of illegally traded African pangolin scales
}

\begin{tabular}{|r|l|}
\hline Journal: & Genome \\
\hline Manuscript ID & gen-2016-0144.R1 \\
\hline Danuscript Type: & Review \\
\hline Complete List of Authors: & $\begin{array}{l}\text { Mwale, Monica; National Zoological Gardens of South Afr, Research and } \\
\text { Scientific Services } \\
\text { Dalton, Desire; National Zoological Gardens of South Afr, Research and } \\
\text { Scientific Services; University of the Free State, Genetics Department } \\
\text { Jansen, Raymond; Tshwane University of Technology, Department of } \\
\text { Environmental, Water and Earth Sciences } \\
\text { Roelofse, Marli; National Zoological Gardens of South Afr, Research and } \\
\text { Scientific Services; University of the Free State, Genetics Department } \\
\text { Pietersen, Darren; African Pangolin Working Group (APWG) } \\
\text { Mokgokong, Prudent; National Zoological Gardens of South Afr, Research } \\
\text { and Scientific Services } \\
\text { Kotze, Antoinette; National Zoological Gardens of South Afr, Research and } \\
\text { Scientific Services; University of the Free State, Genetics Department; } \\
\text { African Pangolin Working Group (APWG) }\end{array}$ \\
\hline Keyword: & $\begin{array}{l}\text { Pangolin, DNA barcoding, Illegal wildlife trade, Forensic genetics, Pangolin } \\
\text { scale confiscation }\end{array}$ \\
\hline & \\
\hline
\end{tabular}

\section{SCHOLARONE ${ }^{m}$}

Manuscripts 


\section{Title}

The forensic application of DNA barcoding for identification of illegally traded African pangolin scales

\section{Author names and affiliations}

Monica Mwale $^{1 *}$, Desire L. Dalton ${ }^{1,2}$, Raymond Jansen ${ }^{3,4}$, Marli Roelofse ${ }^{1,2}$, Darren

Pietersen ${ }^{4}$, Prudent S. Mokgokong ${ }^{1}$, and Antoinette Kotzé ${ }^{1,2,4}$

${ }^{1}$ National Zoological Gardens of South Africa (NZG), P.O. Box 754, Pretoria, 0001, South

Africa

${ }^{2}$ Genetics Department, University of the Free State (UFS), P.O. Box 339, Bloemfontein, 9300

South Africa

${ }^{3}$ Department of Environmental, Water and Earth Sciences, Tshwane University of

Technology (TUT), P/Bag X680, Pretoria, 0001, South Africa

${ }^{4}$ African Pangolin Working Group $(A P W G)$

*Corresponding author

E-mail: monicam@nzg.ac.za, (Tel)+27 12339 2700, (Fax)+27 123234540

\section{Present/permanent address}

National Zoological Gardens of South Africa (NZG), P.O. Box 754, 232 Boom Street, Pretoria, 0001, South Africa. 


\begin{abstract}
The escalating growth in illegal wildlife trade (IWT) and anthropogenic habitat changes threaten the survival of pangolin species worldwide. All eight extant species have experienced drastic population size reductions globally with a high extinction risk in Asia. Consequently, forensic services have become critical for law enforcement, with a need for standardised and validated genetics methods for reliable identifications. The seizure of three tonnes of pangolin scales, believed to have originated from Africa, by Hong Kong Customs Authorities provided an opportunity for the application of DNA barcoding in identifying scales. Three mitochondrial DNA gene regions (COI, Cyt $b$ and D-loop) were amplified for a sub-sample of the confiscation, and compared to taxonomically verified references. All African four species were recovered as monophyletic with high interspecific uncorrected pdistance estimates (0.048-0.188) among genes. However, only three out of four African species (Phataginus tricuspis, P. tetradactyla and Smutsia gigantea) originating from West and Central Africa and one of the four Asian species (M. javanica) from Southeast Asia among scales were identified. Although the assignment of unknown scales to specific species was reliable, additional genetic tools and representative reference material is required in order to determine geographic origins of pangolin confiscations.
\end{abstract}

\title{
Keywords
}

Illegal Wildlife Trade; DNA barcoding; Forensic genetics; Pangolins; Pangolin scale confiscation; Smutsia; Manis 


\section{Introduction}

The illegal poaching and trade of wildlife is a major biodiversity challenge that has contributed to a significant decline in populations of several species in Africa (Challender et al. 2015b). An increase in illegal wildlife trade (IWT) has been documented for all species of pangolin (Family: Manidae) that are exploited for bush meat, and body parts and scales, which have superstitious value and use in traditional medicine in Africa (muthi) and East Asia (Newton et al. 2008, Boakye et al. 2015, Zhang et al. 2015, Nijman et al. 2016). The IWT has been estimated to be worth US\$2.5 billion a year in East Asia and the Pacific, with pangolins contributing an estimated US\$100-150 million in Asia-Pacific (Zhang et al. 2015, Nijman et al. 2016). Therefore, illegal pangolin trade has continued to escalate, with pangolins now being the most trafficked wild mammal species by numbers $(>10,000$ individuals per year) globally (Davis 2014, Challender et al. 2015a). Furthermore, anthropogenic threats such as agricultural intensification have resulted in pangolin declines due to habitat loss and fragmentation (IUCN 2015). Particularly in South Africa, pangolins are electrocuted by electric fencing used on game and livestock farms (Bräutigam et al. 1994, Pietersen et al. 2014a). Pangolins are also considered to be highly vulnerable to extinction, due to their slow growth rates and low reproductive and recovery rates in impacted areas (Pietersen et al. 2014a). There is also very limited information available on the abundance and distribution of all species that are all regarded as data deficient (IUCN 2015, Boakye et al. 2016).

Eight extant species are recognised (Gaudin et al. 2009), with four species distributed (Figure 1) in the Afro-tropics (Giant ground pangolin Smutsia gigantea, Temminck's ground pangolin S. temminckii, Black-bellied pangolin Phataginus tetradactyla and White-bellied pangolin $P$. tricuspis) and four species in the Indo-malayan regions of Asia (Indian pangolin Manis 
crassicaudata, Philippine pangolin M. culionensis, Sunda pangolin M. javanica and Chinese pangolin $M$. pentadactyla). All species are considered to be threatened on the International Union for Conservation of Nature Red List (IUCN 2015), with the four African species listed as Vulnerable (Pietersen et al. 2014b, Waterman et al. 2014a, 2014b, 2014c ) and the Asian species listed as Endangered (two species) (Baillie et al. 2014, Lagrada et al. 2014) and Critically Endangered (two species) (Challender et al. 2014a, 2014b ). All species have now been up listed from Appendix II to Appendix I of the Convention on International Trade in Endangered Species of Wild Fauna and Flora (CITES) at 17th meeting of the Conference of the Parties (CoP17), which bans all international trade and provides for better domestic protection in Asia (Dixon and Weiskotten 2016). Therefore, effectively enforcing the existing legislation to address this unsustainable global criminal enterprise is needed. Reliable and accurate species identification is crucial for forensic investigation of cases where only processed animal parts are confiscated to assist with the monitoring and legal protection of pangolins.

Studies that applied DNA technologies for forensic wildlife species identification have shown that species and even populations can be distinguished with mitochondrial DNA (mtDNA) genes such as cytochrome c oxidase $1(\mathrm{CO} 1)$, cytochrome $b$ (Cyt $b)$ and the control region (D-loop) (Hsieh et al. 2001, Branicki et al. 2003, Ogden and Linacre 2015). For example, the COI gene, which is also considered the standard DNA barcoding region for species identification (Hebert et al. 2003), has shown high levels of distinction among wildlife species (Dawnay et al. 2007, Mwale et al. 2015). While applications of DNA technologies in forensic crime investigation have been conducted for pangolin bush meat and scales (Hsieh et al. 2011, Gaubert et al. 2015, Zhang et al. 2015), these have mainly had a limited species representation, an Asian focus or have only employed analysis of a single mtDNA gene. 
Furthermore, some published GenBank (National Center for Biotechnology Information) sequence data for pangolin species are incorrect and are based on taxonomically misidentified specimens making species assignments unreliable (Hassanin et al. 2015, Gaubert and Antunes 2015). Reference data for different gene markers that would enable reliable forensic identification of all African pangolin species is still lacking at present for legal enforcement of wildlife crimes involving pangolin poaching and seizures.

In this study we report on forensic species identification of a seizure of pangolin scales in Hong Kong using the COI barcoding genes, and Cyt $b$ and D-loop gene regions. Our analysis includes (1) verification of the mtDNA test using Barcode of Wildlife Project (BWP) DNA barcoding reference samples to distinguish between pangolin species, (2) identification of species and the origin of confiscated samples, and (3) analysis of species composition of the confiscated samples.

\section{Materials and Methods}

\section{Sampling and DNA extraction}

Reference tissue voucher specimens $(\mathrm{n}=15)$ of three African pangolin species viz. S. temminckii, $P$. tetradactyla and P. tricuspis, were available from the National Zoological Gardens of South Africa (NZG) (see www.barcodewildlife.org) species reference database (Mwale et al. 2015) (Table 1). All voucher specimens were identified by a taxonomic expert (Ray Jansen; African Pangolin Working Group). Tissue samples of P. tetradactyla and P. tricuspis were collected in West Africa (Figure 2A) (Boakye et al. 2016), while S. temminckii samples were mainly collected in South Africa (Du Toit et al. 2014) (Table 1). In addition, reference samples were supplemented with sequences of $S$. gigantea and two Asian pangolin species (M. javanica and M. pentadactyla) retrieved from GenBank (Qin et al. 2012, 
Hassanin et al. 2015) and the Barcode of Life Data (BOLD) Systems version 4 (beta) for the COI gene (Ratnasingham and Hebert 2007). These sequences were carefully selected to exclude samples where species misidentifications have been reported by recent publications (Hassanin et al. 2015, Gaubert and Antunes 2015). Suitable DNA sequences were available for six of the eight recognised pangolin taxa (Table 1) for testing species boundaries and identification of the unknown scales.

The unidentified pangolin scales are a subset of 3.3 tonnes of scales that were illegally traded and were confiscated by the CITES Management Authority in Hong Kong between 2014 and 2015, and are thought to have originated from Africa. A representative sub-sample of these confiscations consisting of 10 bags, each representing a different consignment with a scale net weight of $27.822 \mathrm{~kg}$, was exported to the National Zoological Gardens of South Africa (NZG) for analysis. Each of the bags was accessioned and assigned a unique NZG biobank accession number. The contents of each bag (Figure 2B) were visually sorted into distinct scale types and were assigned to a species by the taxonomic expert based on their shape, colouration and morphology. A maximum of five samples per scale morph-type (putative species) were selected from each of the 10 bags for molecular characterisation.

Scale samples were pulverised using a dental electric micro-motor drill (Zhengzhou Xinghua Dental Equipment, Henan, China). DNA was extracted using the QIAamp DNA Investigator ${ }^{\circledR}$ Kit (Qiagen Inc., Valencia, California) following the manufacturer's instructions for degraded samples. DNA quantification for purity, concentration and yield was determined by using the NanoDrop ND-1000 Spectrophotometer (Thermo Scientific, Lithuania). Extracted DNA was stored at $-20^{\circ} \mathrm{C}$. 


\section{PCR amplification and sequencing}

Polymerase chain reaction (PCR) was performed in $25 \mu \mathrm{l}$ reactions that consisted of 5-20 ng of template DNA, 12.5 $\mu \mathrm{L}$ 2X DreamTaq PCR Mastermix ( Life Technologies), 10 pmol of each primer (Table 2) and $\mathrm{ddH}_{2} \mathrm{O}$. The thermal cycling conditions were done according to published sources and optimisations as indicated in Table 2 (Kocher et al. 1989, Folmer et al. 1994a). PCR products were visualised on $2 \%$ agarose gel before being purified using the ExoSAP protocol (Thermo Scientific, Lithuania). Purified PCR products were cycle sequenced using the BigDye v3.1 Terminator Kit (Applied Biosystems, Foster City, CA) and then purified with a ZR DNA Sequencing Clean-up Kit (Zymo Research Corporation). Sequencing products were visualised with an ABI 3500 genetic analyser (Applied Biosystems, Foster City, CA).

Sequence assembly and phylogenetic analyses

Consensus sequences for each mtDNA gene were edited and assembled separately and then aligned using MUSCLE (Edgar 2004) in GENEIOUS v8.1.6 (Biomatters, LTD, Auckland, NZ). All mtDNA haplotypes were deposited in GenBank (Table 1). The best-fit model of nucleotide substitution for each dataset was estimated under the Bayesian Information Criterion (BIC) implemented using jMODELTEST 2.1.7 under default parameters (Guindon and Gascuel 2003, Darriba et al. 2012). Neighbour-joining (NJ) analyses were conducted using the selected models of evolution (with invariable sites) in GENEIOUS for all the gene and concatenated datasets. The topology of the NJ tree was confirmed with Bayesian Markov Chain Monte Carlo (MCMC) analyses (BI) as implemented in MRBAYES 3 (Ronquist et al. 2012) in GENEIOUS. Default settings were employed and simulations were run for 1,100,000 generations (Burn-in $=100,000)$ until the standard deviation of split frequencies was below 0.01 . 
Species delimitation in pangolins and forensic identification

Species distinction was evaluated by using the Basic Local Alignment Search Tool (BLAST) of the NCBI searchable database in GENEIOUS, and phylogenetic analyses of sequence characters. The NCBI BLAST (Altschul et al. 1990) uses an alignment program to determine the identity of unknown organisms based on pairwise DNA nucleotide comparisons (percentage matches) of gene sequences accessioned by researchers into this database. The phylogenetic analyses used two different approaches: (1) species tree analyses using each gene and annotated genome sequences and (2) analysis of a concatenated dataset (c-mtDNA) of all three gene fragments. The concatenated dataset was tested for congruence using the Incongruence Length Difference (ILD) Test in PAUP* v. 4.0b10 (Swofford 2002), where critical values for the test are between 0.01 and 0.001 (Farris et al. 1994, Cunningham 1997). Published mtDNA genome gene sequences (Table 1) from the three closely related orders suggested by Hassanin et al. (Hassanin et al. 2015) were used to root the trees.

Species boundaries were verified from the phylogenetic trees using the Species Delimitation Plugin (SDP) in GENEIOUS (Masters et al. 2011) and a standard barcoding gap analysis for the COI data based on Kimura 2-parameter (K2P) distances using the Automatic Barcode Gap Discovery (ABGD) method (Puillandre et al. 2012) with default parameters. The SDP delimits species by evaluating the phylogenetic exclusivity or monophyly of clades by testing the probability of this monophyly occurring by chance in a coalescent process (Masters et al. 2011). SDP also assesses the probability with which a putative species can be diagnosed successfully on a phylogenetic tree by comparing intra- and interspecific genetic distances among well-supported monophyletic clades (Bootstrap $\geq 70 \%$ ). 
The ABGD method uses several prior thresholds for the partitioning of sequences into primary species based on the "barcode gap" that compares the distribution of pairwise differences between intraspecific and interspecific diversity among different species (Hebert et al. 2003) without an a priori species hypothesis. The ABGD analysis estimates the relative gap width $(\mathrm{X})$ and the minimum and maximum values of prior intraspecific divergence $(\mathrm{P})$, which are used to detect the barcode gap using the default K2P model. Default settings of prior minimum genetic distances ranging from 0.001 to 0.1 on the ABGD website (http://wwwabi.snv.jussieu.fr/public/abgd) as these default $P$-values typically produce a range of OTU counts (Puillandre et al. 2012). In both delimitation methods, a species is distinct from its nearest neighbour $(\mathrm{NN})$ if its maximum intraspecific distance is less than the distance to its NN sequence. Barcode gaps between well-supported clades of haplotypes identified by $\mathrm{NJ}$ and BI were taken as an indication of separate Molecular Operational Taxonomic Units (MOTUs). Therefore, barcode gaps and sequence divergences between well-supported clades identified by phylogenetic analyses were taken as an indication of separate species or OTUs.

\section{Results}

Species reference dataset and DNA barcoding analyses

Sequence alignment yielded 600, 400 and 576 base pair (bp) sequence fragments for COI, Cyt $b$ and D-loop, respectively (Table 2). The HKY85 model (Hasegawa et al. 1985) was selected as the best-fit model of evolution for all gene fragments using jMODELTEST. The topologies of the $\mathrm{NJ}$ and $\mathrm{BI}$ gene trees and concatenated mtDNA dataset (Figure 3) were similar with regards to species relationships and clusters. All six reference species $(P$. tricuspis, P. tetradactyla, S. gigantea, S. temminckii, M. javanica and M. pentadactyla) were recovered and well-supported with high $(>70 \%)$ bootstrap support (BS). Interspecific pdistance estimates between all species clades were high, ranging from $0.100-0.188$ (COI) and 
0.10-0.20 (Cyt b) (Tables 3 and 4) and 0.048-0.125 (D-loop). African specimens were also recovered as monophyletic (96-100\% BS: all genes) sharing a most recent common ancestor (MRCA) that was distinct from the Asian pangolin lineage (Manis spp.). All four African pangolin species were further recovered as nearest neighbour taxa or sister-taxa within the two African genera (Figure 3). The concatenated reference dataset (Supplementary, Figure 1) of all genes (ILD tested) produced a fully resolved tree with strong bootstrap (>91\%) and posterior probability $(>0.99)$ support for monophyletic distinction among all species and genera, indicating that a combined gene analysis provides better phylogenetic signal.

The results of the SDP for COI, Cyt $b$ and D-loop analyses using the phylogenetic trees (BI) were similar and are summarised in Table 4. The SDP analyses of all genes provided support for the distinction of all six species having high values for the two $P$ (ID) estimates and their mean probabilities at 95\% confidence intervals (Table 3). This result indicated that the species reference samples were significantly different $(P<0.05)$ from each other and represented distinct species under the same coalescent model of evolution. The mean intraspecific p-distances ranged from 0.001-0.055 (all mtDNA genes) among all species except for M. javanica and P. tricuspis (COI data: 0.037 to 0.030 respectively), which had higher maximum intraspecific divergences suggesting geographic sub-structuring. The observed trend of higher sequence divergence was also reflected in the Cyt $b$ (Table 4) and D-loop (not indicated) analyses for P. tricuspis. The ABGD analyses was robust when comparing specimens of the same species and revealed six genetic groups (MOTUs) that corresponded with the six putative species (Figure 4) being distinct from 3.59-5.99\% COI divergence (Figure 4). The mean overall interspecific p-distance was significantly different $(P<0.05)$ and high $(20.0-22.8 \%)$ between the three genera, providing support for delimitation at the genus level within Manidae. 
Identification of unknown scales - Species assignment tests

DNA from 53 confiscated scales was extracted for species identification. The BLAST searches of all three genes indicated that the scale sequences all had $88-100 \%$ pairwise identity with six pangolin species (P. tricuspis, P. tetradactyla, S. gigantea, S. temminckii, M. javanica and M. pentadactyla) and unidentified Asian records (Manis sp.; 100\% match; Table 5). However, examination of these low pairwise matches (88-90\%) within species showed that these matches were all for comparisons with misidentified GenBank records incorrectly accessioned as $M$. pentadactyla and $P$. tetradactyla, that have been noted by recent studies (Hassanin et al. 2015, Gaubert and Antunes 2015). Although the COI match to S. temminckii was also low (Table 5: 89-90\%), this match was considered to be an interspecific match within Smutsia based on the genetic diversities in the reference data (Table 3). Exclusion of low pairwise matches (interspecific) and misidentified samples improved the BLAST matches to a minimum of 93.4\% (COI), 95.3\% (Cyt $b$ ) and 93.2\% (D-loop). The lowest NCBI BLAST matches (89.0-93.5\%) were all among Manis and Phataginus species records probably due to high intraspecific divergence (COI) and lack of reference material for the Dloop. Furthermore, the high range variation within P. tricuspis (93.4-100\%) which has been noted in the literature (Hassanin et al. 2015) further suggests genetic sub-structuring. Matching sequence identity between scale sequences and the verified reference samples (this study) further improved the accuracy (95-100\%) in matching scales to only four species, $P$. tricuspis, P. tetradactyla, S. gigantea and M. javanica (Table 4). There was no accurate match between the unknown scales and either M. pentadactyla or S. temminckii (Figure 5).

The combined SDP analyses based on reference and unknown scale phylogenetic analyses that tested the probability that the putative species clades had the observed degree of 
distinctiveness, was still higher than the 0.05 threshold $(0.5-0.12)$. The recovered six putative species clades (including scales) had Rodrigo's $P(\mathrm{RD})$ values of $<0.05$ (Table 4, Figure 4) with Rosenberg's $P_{\mathrm{AB}}$ values being significant for all African species $(P<0.05)$, but not for the $M$. javanica species clade $(P>0.11)$, for all datasets. Rodrigo et al. (Rodrigo et al. 2008) define distinctive clades as those that have $P(\mathrm{RD})$ values $<0.05$. High values support species distinction while lower values may suggest cryptic speciation for branching events that would be expected under different coalescent modes (Masters et al. 2011). This result may therefore support the presence of other Asian species among these scales in the "M. javanica" clade (Figure 5).

All of the 10 pangolin bag samples were genetically identified as originating from both African and Asian pangolin species (Table 5). Six of the confiscated bags were of an African origin for three species (S. gigantea, P. tetradactyla and P. tricuspis) while four were of Asian origin, representing M. javanica (100\% node support with reference sequence) and other Asian species (Manis spp.) whose identity could not be verified due to lack of verified species reference data. Species composition analyses indicated that some of the confiscated samples represented multiple pangolin species within one bag (Table 5). One bag (NZG 46070) had multiple Manis species from Asia while two of the bags contained the two African tree pangolin species (P. tetradactyla and P. tricuspis).

\section{Discussion}

The results of the phylogenetic analyses ( $\mathrm{NJ}$ and $\mathrm{BI})$ and independent methods with a priori grouping (ABGD and SPD) that were used to investigate species diversity were generally congruent among the gene fragments and had identical patterns with regards to species identifications. This consistent result for the reference database was critical to ensure accurate 
and reliable assignment of samples of unknown species. This is especially important as the current GenBank database of published pangolin sequences has limited information on African species, with inaccurate information for several pangolin species (Hassanin et al. 2015, Gaubert and Antunes 2015) that can lead to poor confidence in species assignments. The observed interspecific divergence estimates of the reference database (minimum of $10 \%$ between species) was higher than the $2 \%$ that has been observed for reliable distinction among species of vertebrates for the COI and Cyt $b$ regions (Hsieh et al. 2001, Hebert et al. 2003). These values were also within the range observed for D-loop sequences among pangolin species (Zhang et al. 2015). The level of sequence variation between individuals within M. pentadactyla, M. javanica, S. gigantea and S. temminckii was lower than that observed in $P$. tricuspis (up to 7\% BLAST mismatch) suggesting genetic sub-structuring in this latter species. Potential cryptic speciation has been reported in this species(Hassanin et al. 2015), where these authors identified a unique lineage for a Gabon sample in their genomic analyses. Although high intraspecific variation was observed, accurate identification of species was still possible as the unique lineages in $P$. tricuspis were monophyletic and shared a MRCA. Furthermore, the intraspecific pairwise differences were much lower than the interspecific values and were within the expected limit of a "barcode gap" (Puillandre et al. 2012).

The observed differences in the phylogenetic relationships among pangolin species in the COI and Cyt $b$ trees for $S$. gigantea and $S$. temminckii could be attributed to a single locus analysis that can be influenced by incomplete lineage sorting (Hebert et al. 2003), as analysis of the concatenated data produced a resolved tree at all taxonomic levels. This study therefore reinforces the utility of DNA barcoding for species identification using both COI and Cyt $b$ gene regions. The successful use of mtDNA markers in forensic applications for the 
identification of unknown animal samples to species, genus and family levels has been demonstrated by several studies (Hsieh et al. 2001, Verma and Singh 2002, Ogden and Linacre 2015). For example, Verma and Singh (2002), demonstrated the use of Cyt $b$ in the identification of 221 species of animals for forensic cases of processed unknown animal parts. The advantage of mtDNA analysis is that the technology is cost effective and simple enough for individual laboratories even with poor resources to compare sequences for thousands of species (Ratnasingham and Hebert 2007).

Furthermore, results of this study indicate that forensic identification of all African pangolin species are reliable and effective using the COI, Cyt $b$ and D-loop mtDNA gene regions. The gene trees of the combined reference and scale sequence dataset support the monophyly of all identified African groups that were in agreement with current taxonomy with very high support values (e.g. $>94 \%$ for Cyt $b$ ). These monophyletic clades were also different from each other with high levels of divergence providing accurate species identification $(>10 \%$ COI divergence between clades). The mtDNA sequences of scales identified as being from an African origin clustered in the strongly supported monophyletic clades (90-100\% bootstrap support) of three species, viz. S. gigantea, P. tetradactyla and P. tricuspis, to the exclusion of sequences from Asian pangolin species. These three African species have overlapping distributions throughout most of their range in central and western Africa (IUCN 2015). The absence of $S$. temminckii in the confiscation and analyses may suggest that these specific African illegal trade consignments were very likely not of a southern or East African origin. Smutsia temminckii has the largest distribution range of the four African species and is the only pangolin species occurring in southern Africa and over most of East Africa. It is however important to note that this species' absence in the confiscation could also indicate a reduction in the abundance of $S$. temminckii in parts of its range where it marginally co- 
occurs with P. tricuspis. Smutsia gigantea, a sister taxon of S. temminckii, has also been reported to be rare and was only identified in one bag, suggesting that species of this genus may occur at much low densities (Pietersen et al. 2014b) due to previous exploitation events or due to anthropogenic pressure. In southern Africa, the decline in abundance has been mainly associated with habitat loss and transformation (Pietersen et al. 2014a), generally due to agricultural intensification and anthropogenic activities such as electrocutions (electric fencing) as well as on-going poaching and illegal trade (traditional medicines).

This analysis also suggests that all pangolin species, including African species ( $S$. gigantea, P. tetradactyla and P. tricuspis), are targeted regionally and as a group globally with no discrimination among species on the black market. Of the 10 batches that were analysed, three were mixed species bags (P. tetradactyla, P. tricuspis and Asian Manis spp.) with seven batches being unique to a single species. The two Africa origin mixed species bags contained both of the co-occurring tree pangolin species, with $P$. tetradactyla having a range that completely overlaps that of $P$. tricuspis mainly in central Africa. The analyses also indicated the presence of several Asian species in the consignment. Some scale samples were imbedded in a strongly supported monophyletic clade with the verified $M$. javanica reference sequence and had $100 \%$ blast matches with unidentified Manis species. However, this clade was not supported in the SDP, suggesting missing data. Reference samples are therefore required for all Asian pangolin species which have either no reference material (e.g. M. culionensis and M. crassicaudata) or lack specific accurate gene region (M. pentadactyla) datasets in GenBank. However, the absence of a match for $M$. pentadactyla, even with verified reference Cyt $b$ sequences, suggests that this trade consignment may be from a specific area in Asia and can be traced to origin with further analyses. The presence of multiple Asian species in one bag also suggests indiscriminate poaching within Asia for pangolins. 


\section{Conclusion}

These findings suggest that the reported illegal trade confiscation could be from several sources in Africa and Asia and is therefore part of an organised illegal trade enterprise throughout the distribution range of pangolins. Knowing the species targeted by poachers and the areas where poaching activity may be happening is needed to develop and support effective conservation plans by authorities. However, our analyses were not able to refer the confiscated scale samples to any specific populations due to the absence of geographically representative reference material. In addition, population-level markers such as single nucleotide polymorphisms (SNPs) would be required to accurately refer scales of unknown provenance to specific populations. Our analyses suggest that geographic identification would be possible for most pangolin species due to the high levels of intraspecific variation that indicates sub-structuring in African species (P. tricuspis). Further analysis with geographic sampling and a SNP database for African and Asian species will be a powerful tool and will facilitate a better understanding of the geographic origin of pangolin derivatives in trade, allow for better monitoring of this trade and effective law enforcement concerning illegal trade activities involving pangolins.

\section{Acknowledgments}

The authors would like to thank Maxwell Boakye (West Africa) and Amathole Museum (South Africa) for kindly providing reference material for African pangolins. Funding for DNA barcoding (COI) and the collection of chain of custody reference material was provided by the Barcode of Wildlife Project (BWP) through a Google Global Impact Award to the Smithsonian Institute (David Schindel). GIS files for mapping distributions were sourced from the IUCN Red Data List. We would like to thank Zelda Du Toit for advice on DNA 
extraction protocols. Kim Labuschagne, Thando Radebe, Marilise Meyer-Bouwer, Antonie Kloppers and Takalani Musekwa are acknowledged for biobanking assistance and sampling. 


\section{References}

Altschul, S.F., Gish, W., Miller, W., Myers, E.W., and Lipman, D.J. 1990. Basic local alignment search tool. J. Mol. Biol. 215(3): 403-410. doi:http://dx.doi.org/10.1016/S0022-2836(05)80360-2.

Baillie, J., Challander, D., Kaspal, P., Khatiwada, A., Mohapatra, R., and Nash, H. 2014. Manis crassicaudata. IUCN Red List Threat. Species 2014: e.T12761A45221874.en. doi:http://dx.doi.org/10.2305/IUCN.UK.2014-2.RLTS.T12761A45221874.en.

Boakye, M.K., Kotzé, A., Dalton, D.L., and Jansen, R. 2016. Unravelling the pangolin bushmeat commodity chain and the extent of trade in Ghana. Hum. Ecol.: 1-8. doi:10.1007/s10745-016-9813-1.

Boakye, M.K., Pietersen, D.W., Kotzé, A., Dalton, D.L., and Jansen, R. 2015. Knowledge and uses of African pangolins as a source of traditional medicine in Ghana. PLoS One 10(1): e0117199. doi:10.1371/journal.pone.0117199.

Branicki, W., Kupiec, T., and Pawlowski, R. 2003. Validation of cytochrome b sequence analysis as a method of species identification. J. Forensic Sci. 48(1): 83-87.

Bräutigam, A., Howes, J., Humphreys, T., and Hutton, J. 1994. Recent information on the status and utilization of African pangolin. TRAFFIC 15(1): 15-22.

Challender, D., Baillie, J., Ades, G., Kaspal, P., Chan, B., Khatiwada, A., Xu, L., Chin, S., KC, R., Nash, H., and Hsieh, H.-M. 2014a. Manis pentadactyla. IUCN Red List Threat. Species 2014: e.T12764A45222544.en. doi:http://dx.doi.org/10.2305/IUCN.UK.20142.RLTS.T12764A45222544.en.

Challender, D., Nguyen Van, T., Shepard, C., Krishnasamy, K., Wang, A., Lee, B., Panjang, E., Fletcher, L., Heng, S., Seah Han Ming, J., Olsson, A., Nguyen The Truong, A., Nguyen Van, Q., and Chung, Y. 2014b. Manis javanica. IUCN Red List Threat. Species 2014: e.T12763A45222303.en. doi:http://dx.doi.org/10.2305/IUCN.UK.2014- 


\section{RLTS.T12763A45222303.en.}

Challender, D.W.S., Harrop, S.R., and MacMillan, D.C. 2015a. Understanding markets to conserve trade-threatened species in CITES. Biol. Conserv. 187: 249-259. doi:10.1016/j.biocon.2015.04.015.

Challender, D.W.S., Harrop, S.R., and MacMillan, D.C. 2015b. Towards informed and multifaceted wildlife trade interventions. Glob. Ecol. Conserv. 3: 129-148. doi:10.1016/j.gecco.2014.11.010.

Cunningham, C.W. 1997. Can three incongruence tests predict when data should be combined? Mol. Biol. Evol. 14(7): 733-740. doi:http://dx.doi.org/10.1093/oxfordjournals.molbev.a025813.

Darriba, D., Taboada, G.L., Doallo, R., and Posada, D. 2012. jModelTest 2: more models, new heuristics and parallel computing. Nat Meth 9(8): 772. http://dx.doi.org/10.1038/nmeth.2109.

Davis, E. 2014. 'Shocking' scale of pangolin smuggling revealed. Available from http://www.bbc.co.uk/nature/26549963 [accessed 22 January 2016].

Dawnay, N., Ogden, R., McEwing, R., Carvalho, G.R., and Thorpe, R.S. 2007. Validation of the barcoding gene COI for use in forensic genetic species identification. Forensic Sci. Int. 173(1): 1-6. doi:10.1016/j.forsciint.2006.09.013.

Du Toit, Z., Grobler, J.P., Kotzé, A., Jansen, R., Brettschneider, H., and Dalton, D.L. 2014. The complete mitochondrial genome of temminck's ground pangolin (Smutsia temminckii; Smuts, 1832) and phylogenetic position of the Pholidota (Weber, 1904). Gene 551(1): 49-54. doi:10.1016/j.gene.2014.08.040.

Edgar, R.C. 2004. MUSCLE: multiple sequence alignment with high accuracy and high throughput. Nucleic Acids Res. 32(5): 1792-1797. doi:10.1093/nar/gkh340.

Farris, J.S., Källersjö, M., Kluge, A.G., and Bult, C. 1994. Testing significance of 
incongruence. Cladistics 10(3): 315-319. doi:10.1111/j.1096-0031.1994.tb00181.x.

Folmer, O., Black, M., Hoeh, W., Lutz, R., and Vrijenhoek, R. 1994a. DNA primers for amplification of mitochondrial cytochrome c oxidase subunit I from diverse metazoan invertebrates. Mol. Mar. Biol. Biotechnol. 3(5): 294-299.

doi:10.1371/journal.pone.0013102.

Folmer, O., Black, M., Hoeh, W., Lutz, R., and Vrijenhoek, R. 1994b. DNA primers for amplification of mitochondrial cytochrome c oxidase subunit I from diverse metazoan invertebrates. Mol. Mar. Biol. Biotechnol. 3(5): 294-299.

Gaubert, P., and Antunes, A. 2015. What's behind these scales? Comments to 'The complete mitochondrial genome of Temminck's ground pangolin (Smutsia temminckii; Smuts, 1832) and phylogenetic position of the Pholidota (Weber, 1904)'. Gene 563(1): 106-8. doi:10.1016/j.gene.2015.03.021.

Gaubert, P., Njiokou, F., Olayemi, A., Pagani, P., Dufour, S., Danquah, E., Nutsuakor, M.E.K., Ngua, G., Missoup, A.-D., Tedesco, P.A., Dernat, R., and Antunes, A. 2015. Bushmeat genetics: setting up a reference framework for the DNA typing of African forest bushmeat. Mol. Ecol. Resour. 15(3): 633-651. doi:10.1111/1755-0998.12334.

Gaudin, T.J., Emry, R.J., and Wible, J.R. 2009. The phylogeny of living and extinct pangolins (mammalia, pholidota) and associated taxa: A morphology based analysis. J. Mamm. Evol. 16(4): 235-305. doi:10.1007/s10914-009-9119-9.

Guindon, S., and Gascuel, O. 2003. A simple, fast, and accurate algorithm to estimate large phylogenies by maximum likelihood. Syst. Biol. 52(5): 696-704. doi:10.1080/10635150390235520.

Hasegawa, M., Kishino, H., and Yano, T. 1985. Dating of the human-ape splitting by a molecular clock of mitochondrial DNA. J. Mol. Evol. 21: 160-174. doi:10.1007/BF02101694. 
Hassanin, A., Hugot, J.-P., and van Vuuren, B.J. 2015. Comparison of mitochondrial genome sequences of pangolins (Mammalia, Pholidota). C. R. Biol. 338(4): 260-5. doi:10.1016/j.crvi.2015.02.003.

Hebert, P.D.N., Cywinska, A., Ball, S.L., and deWaard, J.R. 2003. Biological identifications through DNA barcodes. Proc. Biol. Sci. 270(1512): 313-21. doi:10.1098/rspb.2002.2218.

Hsieh, H.M., Chiang, H.L., Tsai, L.C., Lai, S.Y., Huang, N.E., Linacre, A., and Lee, J.C.I. 2001. Cytochrome b gene for species identification of the conservation animals. Forensic Sci. Int. 122(1): 7-18. doi:10.1016/S0379-0738(01)00403-0.

Hsieh, H.M., Lee, J.C.I., Wu, J.H., Chen, C.A., Chen, Y.J., Wang, G.B., Chin, S.C., Wang, L.C., Linacre, A., and Tsai, L.C. 2011. Establishing the pangolin mitochondrial D-loop sequences from the confiscated scales. Forensic Sci. Int. Genet. 5(4): 303-307. doi:10.1016/j.fsigen.2010.06.003.

IUCN. 2015. The IUCN Red List of Threatened Species. Version 2015-4. Available from www.iucnredlist.org [accessed 20 January 2016].

Kocher, T.D., Thomas, W.K., Meyer, A., Edwards, S. V, Pääbo, S., Villablanca, F.X., and Wilson, A.C. 1989. Dynamics of mitochondrial DNA evolution in animals: amplification and sequencing with conserved primers. Proc. Natl. Acad. Sci. U. S. A. 86(16): 6196-6200. doi:10.1073/pnas.86.16.6196.

Lagrada, L., Schoppe, S., and Challander, D. 2014. Manis culionensis. IUCN Red List Threat. Species 2014: e.T136497A45223365.en. doi:http://dx.doi.org/10.2305/IUCN.UK.2014-2.RLTS.T136497A45223365.en.

Masters, B.C., Fan, V., and Ross, H.A. 2011. Species delimitation - a Geneious plugin for the exploration of species boundaries. Mol. Ecol. Resour. 11(1): 154-157. doi:10.1111/j.1755-0998.2010.02896.x. 
Mwale, M., Dalton, D.L., Roelofse, M., Radebe, T., Labuschagne, K., Kloppers, A., Musekwa, T., Parusnath, S., and Kotze, A. 2015. Progress in the barcoding of illegally traded South African wildlife species at the National Zoological Gardens of South Africa. In Genome. Canadian Science Publishing, NRC Research Press, 65 Auriga Dr, Suite 203, Ottawa, ON K2E 7W6, Canada. pp. 259-260.

Newton, P., Van Thai, N., Roberton, S., and Bell, D. 2008. Pangolins in peril: Using local hunters' knowledge to conserve elusive species in Vietnam. Endanger. Species Res. 6(1): 41-53. doi:10.3354/esr00127.

Nijman, V., Zhang, M.X., and Shepherd, C.R. 2016. Pangolin trade in the Mong La wildlife market and the role of Myanmar in the smuggling of pangolins into China. Glob. Ecol. Conserv. 5: 118-126. doi:10.1016/j.gecco.2015.12.003.

Ogden, R., and Linacre, A. 2015. Wildlife forensic science: A review of genetic geographic origin assignment. Forensic Sci. Int. Genet. 18: 152-9. doi:10.1016/j.fsigen.2015.02.008.

Pietersen, D.W., McKechnie, A.E., and Jansen, R. 2014a. Home range, habitat selection and activity patterns of an arid-zone population of Temminck's ground pangolins, Smutsia temminckii. African Zool. 49(2): 265-276. doi:10.3377/004.049.0215.

Pietersen, D.W., Waterman, C., Hywood, L., Rankin, P., and Soewu, D. 2014b. Smutsia temminckii. IUCN Red List Threat. Species: e.T12765A45222717. doi:http://dx.doi.org/10.2305/IUCN.UK.2014-2.RLTS.T12765A45222717.en.

Puillandre, N., Lambert, A., Brouillet, S., and Achaz, G. 2012. ABGD, Automatic Barcode Gap Discovery for primary species delimitation. Mol. Ecol. 21(8): 1864-1877. doi:10.1111/j.1365-294X.2011.05239.x.

Qin, X.-M., Dou, S.-R., Guan, Q.-X., Qin, P.-S., and She, Y. 2012. Complete mitochondrial genome of the Manis pentadactyla (Pholidota, Manidae): comparison of $M$. 
pentadactyla and M. tetradactyla. Mitochondrial DNA 23(1): 37-38.

doi:10.3109/19401736.2011.643881.

Ratnasingham, S., and Hebert, P.D.N. 2007. BOLD: The Barcode of Life Data System (http://www.barcodinglife.org). Mol. Ecol. Notes 7(3): 355-364. Ltd. doi:10.1111/j.1471-8286.2007.01678.x.

Rodrigo, A., Bertels, F., Heled, J., Noder, R., Shearman, H., and Tsai, P. 2008. The perils of plenty: what are we going to do with all these genes? Philos. Trans. R. Soc. Lond. B. Biol. Sci. 363(1512): 3893-3902. doi:10.1098/rstb.2008.0173.

Ronquist, F., Teslenko, M., van der Mark, P., Ayres, D.L., Darling, A., Höhna, S., Larget, B., Liu, L., Suchard, M.A., and Huelsenbeck, J.P. 2012. MrBayes 3.2: Efficient Bayesian phylogenetic inference and model choice across a large model space. Syst. Biol. 61(3): 539-542. doi:10.1093/sysbio/sys029.

Swofford, D.L. 2002. PAUP*. Phylogenetic Analysis Using Parsimony (*and Other Methods). Sinauer Associates, Inc., Sunderland, Massachusetts.

Verma, S.K., and Singh, L. 2002. Novel universal primers establish identity of an enormous number of animal species for forensic application. Mol. Ecol. Notes 3(1): 28-31. doi:10.1046/j.1471-8286.2003.00340.x.

Waterman, C., Pietersen, D., Hywood, L., Rankin, P., and Soewu, D. 2014a. Smutsia gigantea. IUCN Red List Threat. Species 2014: e.T12762A45222061. doi:http://dx.doi.org/10.2305/IUCN.UK.2014-2.RLTS.T12762A45222061.en.

Waterman, C., Pietersen, D., Soewu, D., Hywood, L., and Rankin, P. 2014b. Phataginus tetradactyla. IUCN Red List Threat. Species 2014: e.T12766A45222929.en. doi:http://dx.doi.org/10.2305/IUCN.UK.2014-2.RLTS.T12766A45222929.en.

Waterman, C., Pietersen, D., Soewu, D., Hywood, L., and Rankin, P. 2014c. Phataginus tricuspis. IUCN Red List Threat. Species: e.T12767A45223135. 
doi:http://dx.doi.org/10.2305/IUCN.UK.2014-2.RLTS.T12767A45223135.en.

Dixon, M., and Weiskotten, C. 2016. CITES CoP17: Victory Today for Pangolins [online]. Available from https://newsroom.wcs.org/NewsReleases/articleType/ArticleView/articleId/9303/[accessed 07 October 2005].

Zhang, H., Miller, M.P., Yang, F., Chan, H.K., Gaubert, P., Ades, G., and Fischer, G.A. 2015. Molecular tracing of confiscated pangolin scales for conservation and illegal trade monitoring in Southeast Asia. Glob. Ecol. Conserv. 4: 414-422. doi:10.1016/j.gecco.2015.08.002. 
1 Table 1. GenBank accession numbers and sampling localities of DNA sequence data that was used in the species reference dataset and as out 2 groups. Reference pangolin species sequences (bold font) are published and verified genome or gene sequences of each species.

\begin{tabular}{|c|c|c|c|c|}
\hline Species & Locality & COI & Cyt b & D-loop \\
\hline Smutsia gigantea & Cameroon* & KJ192837-8 & KJ193382 & unavailable \\
\hline \multirow{2}{*}{ Smutsia temminckii } & Tanzania† & KP306515 & KP306515 & KP306515 \\
\hline & South Africa (NZG reference) & KX012661 & Submitted & Submitted \\
\hline \multirow{2}{*}{ Phataginus tetradactyla } & Cameroon* & KJ192841-2 & unavailable & unavailable \\
\hline & Ghana (NZG reference) & KX012676, KX012678-79, KX012684 & Submitted & Submitted \\
\hline \multirow{3}{*}{ Phataginus tricuspis } & Gabont & KP306514 & KP306514 & KP306514 \\
\hline & Cameroon, Ghana \& Nigeria* & KJ192992, KJ192849 & KJ193401-02, KJ193526 & unavailable \\
\hline & Ghana (NZG reference) & KX012680-85 & Submitted & Submitted \\
\hline \multirow[t]{2}{*}{ Manis javanica } & Thailand $†$ & KP306516 & KP306516 & KP306516 \\
\hline & Malaysiał & KF007331 & unavailable & unavailable \\
\hline \multirow{3}{*}{ Manis pentadactyla } & China§ & KC690306-7 & unavailable & unavailable \\
\hline & Thailand\| & unavailable & KP261032 & unavailable \\
\hline & & & KP261034 & \\
\hline Canis latrans & USA, Nebraskał & NC_008093 & NC_008093 & NC_008093 \\
\hline Ceratotherium simum & - & $\mathrm{NC}^{-} 001808$ & $\mathrm{NC}^{-} 001808$ & $\mathrm{NC}^{-} 001808$ \\
\hline Rhinolophus monoceros & - & $\mathrm{NC}-005433$ & NC_005433 & NC_005433 \\
\hline
\end{tabular}

3 Reference sequences were sourced from: the NZG reference database, ${ }^{*}=$ Gaubert et al. (2015), $\dagger=$ Hassanin et al. (2015), $\ddagger=$ GenBank sequence, $\S=$ Qin et al. (2012) and $\|=$ Gaubert and Antunes (2015). 
7 Table 2. PCR conditions and primer sequences used for sequencing three pangolin mitochondrial DNA gene fragments. Sequence information 8 for the different gene fragments are also indicated.

\begin{tabular}{|c|c|c|c|c|c|c|c|}
\hline Gene & PCR cycling conditions & Primers & Source & $\begin{array}{l}\text { Fragment } \\
\text { Length }\end{array}$ & $\begin{array}{l}\text { BIC best- } \\
\text { fit model }\end{array}$ & $\begin{array}{l}\text { Variable } \\
\text { sites (PS) }\end{array}$ & $\begin{array}{l}\text { Informative } \\
\text { sites (PI) }\end{array}$ \\
\hline COI & $\begin{array}{l}40 \text { cycles: } 30 \mathrm{~s} \text { at } 94^{\circ} \mathrm{C}, 40 \mathrm{~s} \text { at } 45^{\circ} \mathrm{C}(\mathrm{x} 5) \\
\& 51^{\circ} \mathrm{C}(\mathrm{x} 35), 90 \mathrm{~s} \text { at } 72^{\circ} \mathrm{C}\end{array}$ & $\begin{array}{l}\text { dgLCO1490, dgHCO2198 } \\
\text { Pan6AF, PAN6AR }\end{array}$ & $\begin{array}{l}\text { Folmer et al. } 1994 \\
\text { Du Toit et al. } 2014\end{array}$ & $600 \mathrm{bp}$ & $\begin{array}{l}\mathrm{HKY}+\mathrm{I} \\
(\mathrm{I}=0.631)\end{array}$ & $\begin{array}{l}200 \\
(33.0 \%)\end{array}$ & $\begin{array}{l}147 \\
(24.5 \%)\end{array}$ \\
\hline Cyt $b$ & $\begin{array}{l}15 \text { cycles: } 30 \mathrm{~s} \text { at } 94^{\circ} \mathrm{C}, 50 \mathrm{~s} \text { at } 60^{\circ} \mathrm{C}(\mathrm{x} 5) \& \\
55^{\circ} \mathrm{C}(\mathrm{x} 10), 60 \mathrm{~s} \text { at } 72^{\circ} \mathrm{C}\end{array}$ & Cytb_Univ1, Cytb_Univ2 & Kocher et al. 1989 & $400 \mathrm{bp}$ & $\begin{array}{l}\mathrm{HKY}+\mathrm{I} \\
(\mathrm{I}=0.631)\end{array}$ & $133(33.2 \%)$ & $\begin{array}{l}109 \\
(27.2 \%)\end{array}$ \\
\hline D-loop & $\begin{array}{l}\text { 30cycles: } 30 \mathrm{~s} \text { at } 94^{\circ} \mathrm{C}, 30 \mathrm{~s} \text { at } 50^{\circ} \mathrm{C}, 45 \mathrm{~s} \text { at } \\
72^{\circ} \mathrm{C}\end{array}$ & Pan_15A_F, Pan_15A_R & Hsieh et al. 2011 & 576 bp & $\begin{array}{l}\mathrm{HKY}+\mathrm{G} \\
(\mathrm{G}=0.267)\end{array}$ & $131(22.7 \%)$ & $\begin{array}{l}114 \\
(19.8 \%)\end{array}$ \\
\hline All genes & - & - & - & $1576 \mathrm{bp}$ & $\begin{array}{l}\mathrm{HKY}+\mathrm{G} \\
(\mathrm{G}=0.170)\end{array}$ & $430(27.3 \%)$ & $\begin{array}{l}217 \\
(13.8 \%)\end{array}$ \\
\hline
\end{tabular}


11 Table 3. Interspecific sequence divergence estimates (mean \pm standard error) for the COI (above diagonal) and Cyt $b$ (below diagonal) gene 12 regions of the species reference dataset.

\begin{tabular}{|l|l|l|l|l|l|l|}
\hline Species & S. gigantea & S. temminckii & P. tetradactyla & P. tricuspis & M. javanica & M. pentadactyla \\
\hline Smutsia gigantea & & $0.115 \pm 0.013$ & $0.183 \pm 0.016$ & $0.160 \pm 0.016$ & $0.150 \pm 0.014$ & $0.180 \pm 0.016$ \\
\hline Smutsia temminckii & $0.103 \pm 0.017$ & & $0.185 \pm 0.016$ & $0.188 \pm 0.016$ & $0.182 \pm 0.015$ & $0.177 \pm 0.015$ \\
\hline Phataginus tetradactyla & $0.134 \pm 0.018$ & $0.161 \pm 0.019$ & & $0.150 \pm 0.014$ & $0.149 \pm 0.014$ & $0.100 \pm 0.012$ \\
\hline Phataginus tricuspis & $0.144 \pm 0.019$ & $0.145 \pm 0.019$ & $0.151 \pm 0.019$ & & $0.102 \pm 0.012$ & $0.165 \pm 0.015$ \\
\hline Manis javanica & $0.162 \pm 0.016$ & $0.160 \pm 0.016$ & $0.174 \pm 0.016$ & $0.106 \pm 0.011$ & & $0.145 \pm 0.013$ \\
\hline Manis pentadactyla & $0.199 \pm 0.022$ & $0.196 \pm 0.022$ & $0.200 \pm 0.021$ & $0.179 \pm 0.021$ & $0.154 \pm 0.016$ & \\
\hline
\end{tabular}

13 
Table 4. Summary statistics of the Species Delimitation plugin analyses for the COI and Cyt $b$ gene region datasets among six pangolin species. The Cyt $b$ values are indicated in brackets when different from the COI estimates. Scales ID $=$ species identifications of confiscated scales that were identified during this study; $\mathrm{SGI}=$ Smutsia gigantea $; \mathrm{STE}=$ S. temminckii; $\mathrm{PTR}=$ Phataginus tricuspis; $\mathrm{PTE}=$ P. tetradactyla $; \mathrm{MJA}=$ Manis

javanica; MPE $=$ M. pentadactyla,

\begin{tabular}{|c|c|c|c|c|c|c|c|c|c|c|}
\hline $\begin{array}{c}\text { Species } \\
\text { reference }\end{array}$ & $\mathbf{N}$ & $\begin{array}{c}\text { Intra } \\
\text { Distance }\end{array}$ & $\mathbf{N N}$ & $\begin{array}{c}\text { Inter } \\
\text { Distance - NN }\end{array}$ & $\begin{array}{l}\text { Intra } \\
\text { /Inter }\end{array}$ & $\begin{array}{c}\text { P ID(Strict) } \\
\text { COI }\end{array}$ & $\begin{array}{c}\text { P ID(Strict) } \\
\text { Cyt } b\end{array}$ & $\begin{array}{c}\text { Av } \\
\text { (MRCA-tips) }\end{array}$ & $\begin{array}{c}\text { Rodrigo's } \\
\text { P(Randomly } \\
\text { Distinct) }\end{array}$ & $\begin{array}{c}\text { Rosenberg's } \\
\mathbf{P}_{\mathrm{AB}}\end{array}$ \\
\hline 1: SGI & 2 & 0.003 & 2: STE & $0.113(0.113)$ & 0.030 & $0.58(0.43,0.73)$ & $0.59(0.44,0.74)$ & $0.0001(0)$ & 0.05 & $0.03(0.02)$ \\
\hline 2: STE & 4 & $0.010(0.003)$ & 1: SGI & & 0.090 & $0.81(0.67,0.95)$ & $0.91(0.79,1.00)$ & $0.0081(0.0035)$ & 0.05 & $0.03(0.02)$ \\
\hline 3: PTR & 6 & $0.030(0.055)$ & 4: PTE (SGI) & $0.162(0.177)$ & 0.190 & $0.91(0.85,0.98)$ & $0.80(0.69,0.90)$ & $0.0309(0.0527)$ & $0.12(0.70)$ & $<10^{-4}$ \\
\hline 4: PTE & 8 & $0.009(0.004)$ & 3: PTR (SGI) & $(0.168)$ & 0.060 & $0.92(0.81,1.00)$ & $0.92(0.80,1.00)$ & $0.0081(0.0052)$ & 0.05 & $<10^{-4}$ \\
\hline 5: MJA & 2 & $0.029(0.001)$ & 6: MPE & $0.175(0.147)$ & 0.170 & $0.51(0.36,0.66)$ & $0.79(0.61,0.96)$ & $0.0182(0.0008)$ & $0.08(0.05)$ & $0.11(0.02)$ \\
\hline 6: MPE & 2 & $0.003(0.004)$ & 5: MJA & & 0.020 & $0.58(0.43,0.73)$ & $0.77(0.60,0.95)$ & $0.0011(0.0036)$ & 0.05 (N/A) & $0.11(0.02)$ \\
\hline \multicolumn{11}{|l|}{ Scales ID } \\
\hline 1: SGI & & 0.006 & 2: STE & 0.006 & 0.127 & & $0.84(0.69,0.98)$ & 0.0043 & 0.05 & $4.08 \mathrm{E}-03$ \\
\hline 2: STE & & 0.011 & 1: SGI & 0.011 & 0.127 & & $0.81(0.67,0.95)$ & 0.0085 & 0.05 & $4.08 \mathrm{E}-03$ \\
\hline 3: PTR & & 0.032 & 4: PTE & 0.132 & 0.250 & & $0.91(0.86,0.97)$ & 0.0284 & 0.05 & $9.1 \mathrm{E}-9$ \\
\hline 4: PTE & & 0.015 & 3: PTR & 0.132 & 0.110 & & $0.92(0.83,1.00)$ & 0.0161 & 0.05 & $9.1 \mathrm{E}-9$ \\
\hline 5: MJA & & 0.037 & 6: MPE & 0.154 & 0.240 & & $0.47(0.32,0.62)$ & 0.0184 & 0.05 & 0.11 \\
\hline 6: MPE & & 0.002 & 5: MJA & 0.154 & 0.010 & & $0.58(0.43,0.73)$ & 0.0010 & 0.05 & 0.11 \\
\hline
\end{tabular}


Table 5. Species identification results from the amplified genes and top similarity matches (BLAST) of confiscated scales batches (NZG numbers) to the sequences from NCBI (in brackets). The species matches in bold font indicate the NCBI sequence matches of records noted as species misidentifications from publications that were within the range of closely related pangolin species.

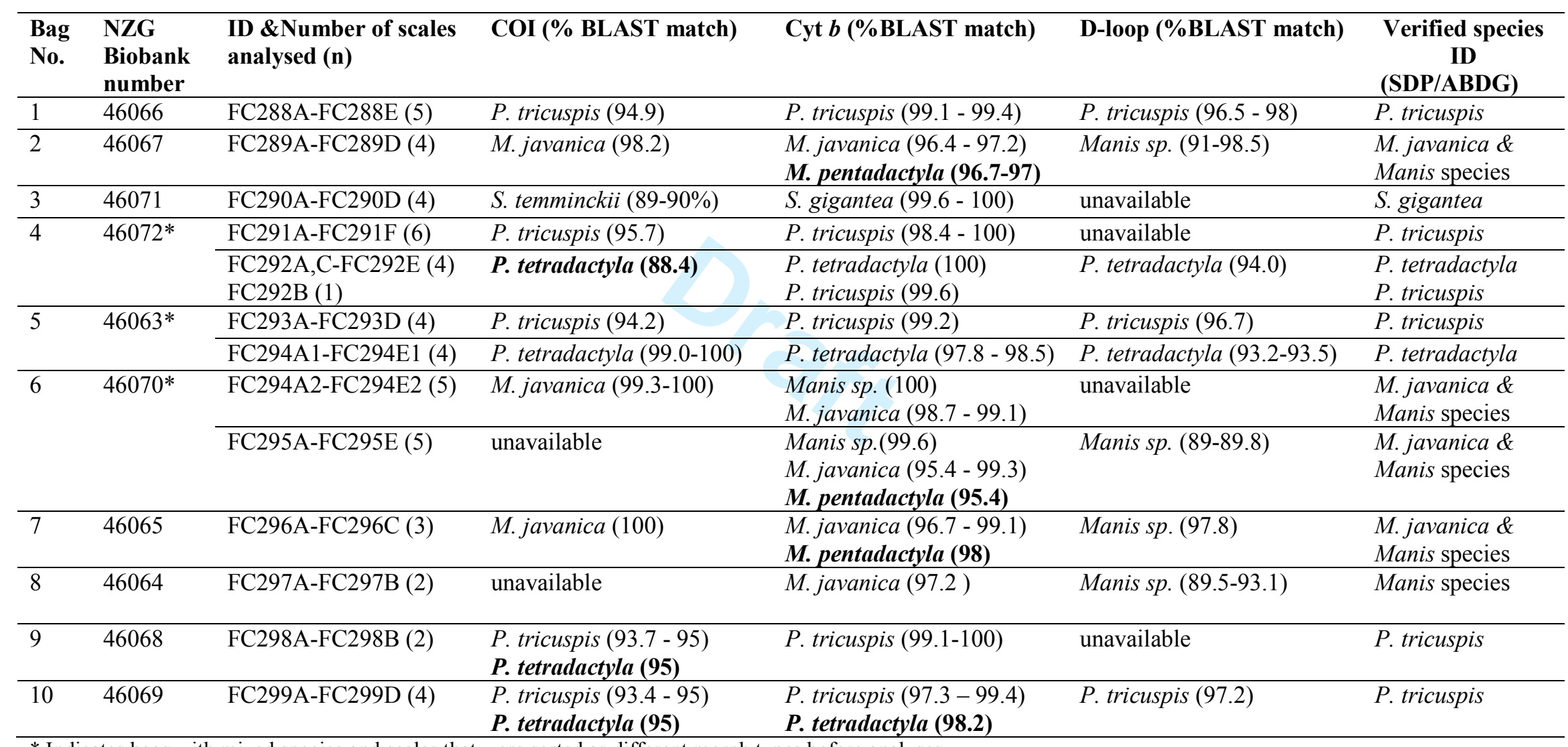

\footnotetext{
* Indicates bags with mixed species and scales that were sorted as different morph types before analyses.
} 


\section{FIGURE CAPTIONS}

Figure 1. Global distribution of pangolin species according to the IUCN Red Data list of species (IUCN, 2015). The sampling sites where the reference material for three African pangolin species was collected $(\odot)$ are also indicated. *Inset map is for the Philippine pangolin distribution.

Figure 2: Pangolins from the bush meat trade in West Africa (A) and scales from the Hong Kong confiscation (B).

Figure 3. Interspecific and intraspecific relationships among African (black bars) and Asian (grey bars) pangolin species used as reference material for the Cyt $b$ (A) and COI (B) datasets. Values on the branches are bootstrap support values (below) and posterior probabilities (above; only posterior probabilities $>0.95$ are indicated) for all the phylogenetic analyses. Support values of the D-loop dataset received 100\% bootstrap and 1.00 posterior probability support for all clades and all species and are therefore not indicated. Black nodes indicate sub-structuring in P. tricuspis.

Figure 4. Results of the Automatic Barcode Gap Discovery (ABDG) COI analyses of the mtDNA COI gene using Kimura-2-Parameter (K2P) distances. This analysis was for prior intraspecific divergences for the reference dataset of six putative species based on the distance at which a barcode gap occurs.

Figure 5. Phylogeny of the pangolin scales that were confiscated in Hong Kong in comparison to the reference species dataset (bold) based on Cyt $b$ mitochondrial DNA sequences. Neighbour-Joining bootstrap values (below) and Bayesian Inference posterior probability values (above) are indicated on the branches. Missing support values (-) indicate lack of significant BS or PP support for the clade. Clades that were not identified among the confiscated scales are indicated by blue bars.

\section{SUPPLEMENT}

Figure S1: Interspecific and intraspecific relationships among African (black bar) and Asian (grey bar) pangolin species used as reference material for the combined COI, Cyt $b$ and D- 
62 loop datasets. Bootstrap support (below) and Bayesian posterior probability (above) value 63 estimates are indicated on the branches. Black nodes indicate sub-structuring in P. tricuspis. 64

65 


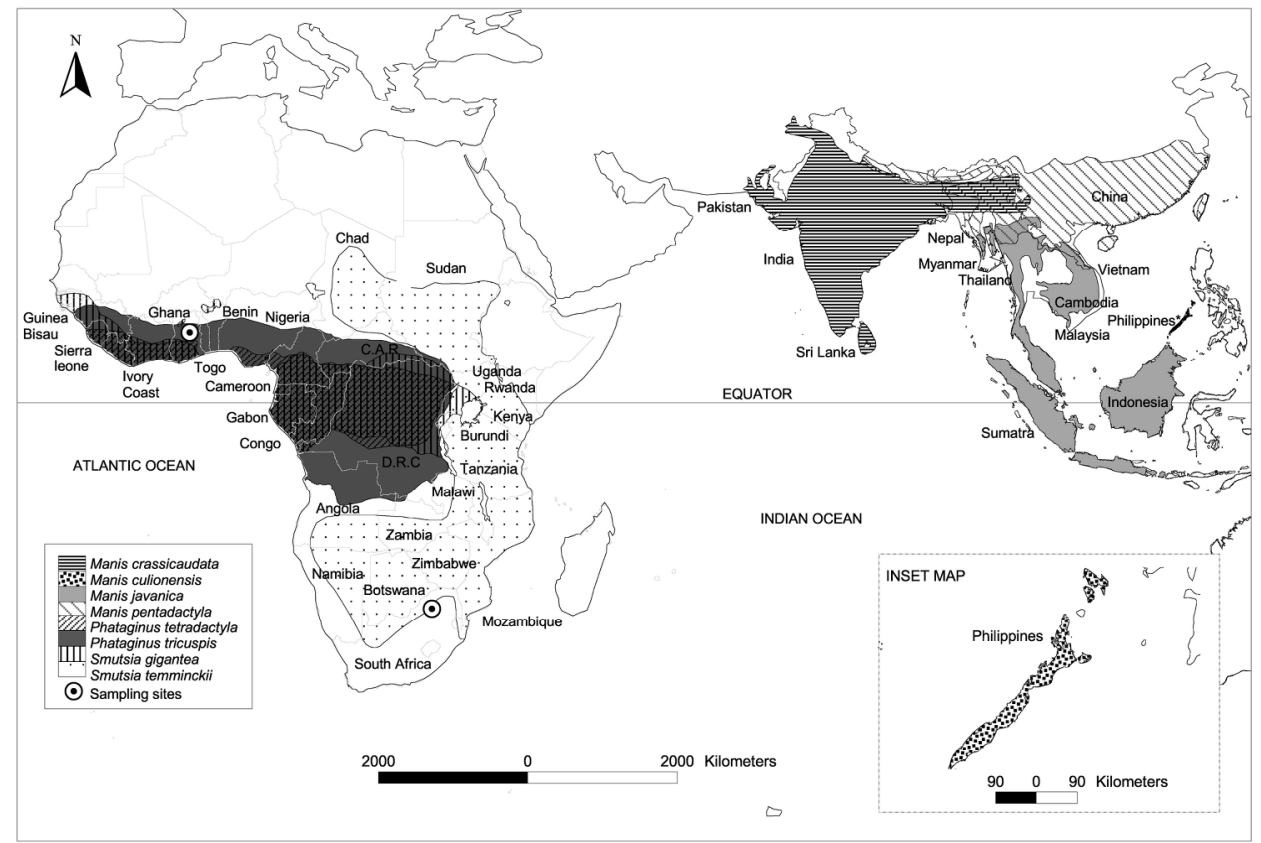

Global distribution of pangolin species according to the IUCN Red Data list of species (IUCN, 2015). The sampling sites where the reference material for three African pangolin species was collected (dotted circles) are also indicated. *Inset map is for the Philippine pangolin distribution.

Figure 1

$201 \times 140 \mathrm{~mm}(300 \times 300$ DPI) 

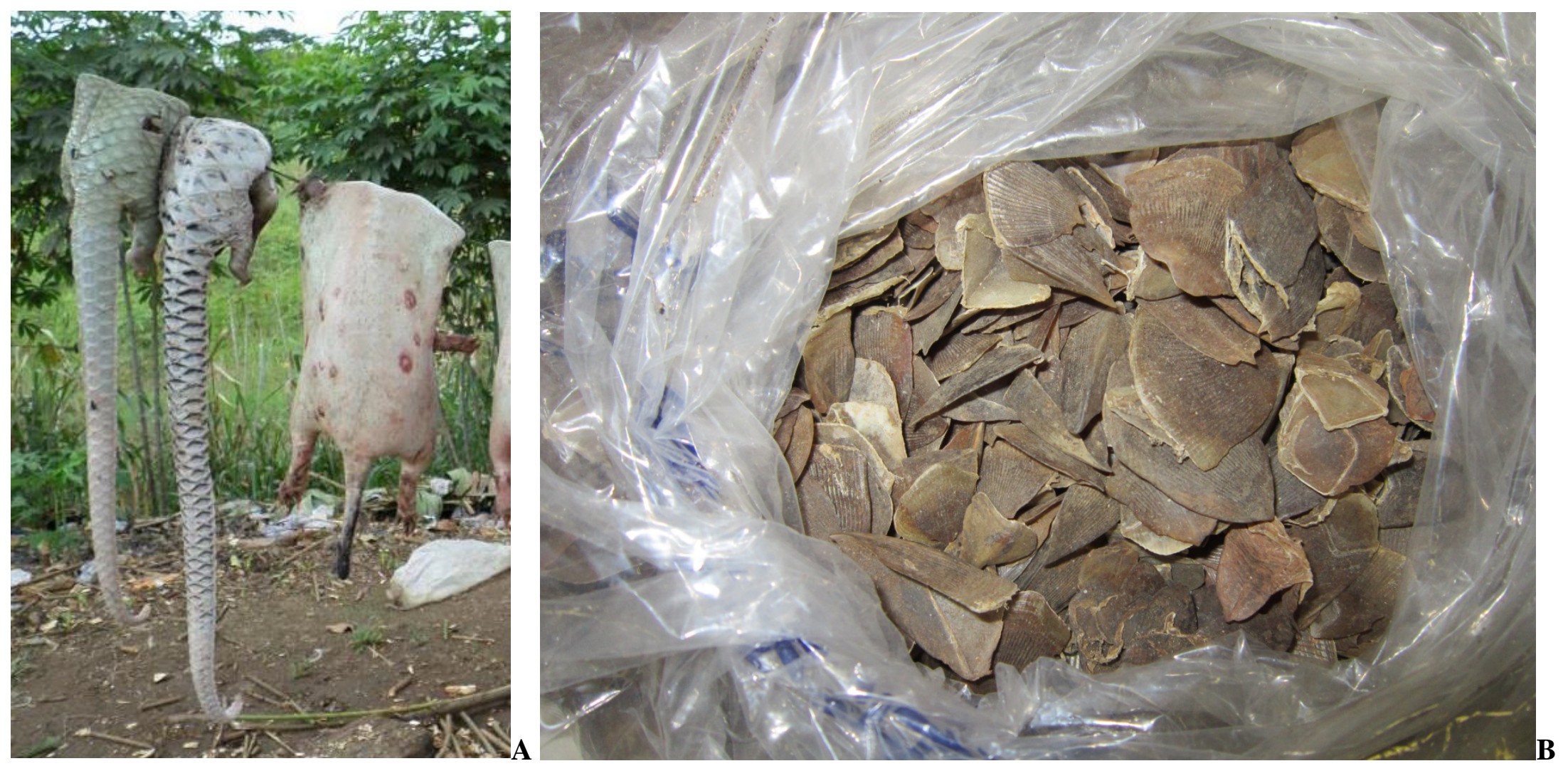


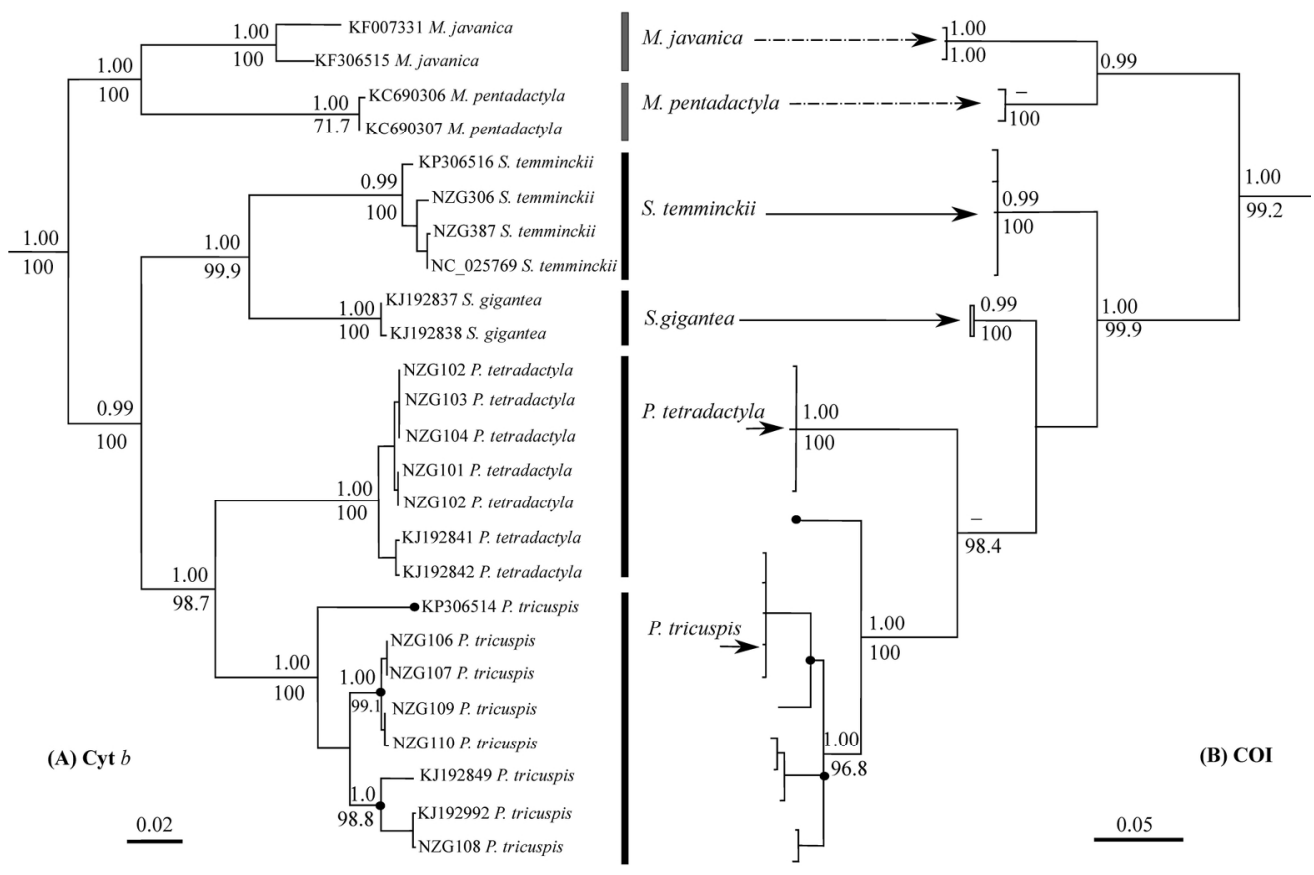

Interspecific and intraspecific relationships among African (black bars) and Asian (grey bars) pangolin species used as reference material for the Cyt $b(\mathrm{~A})$ and COI (B) datasets. Values on the branches are bootstrap support values (below) and posterior probabilities (above) for the Automatic Barcode Gap Discovery (ABGD) COI analyses and the Cyt $b$ data. Analyses of D-loop received $100 \%$ bootstrap and posterior probability support for all clades and all species, and these values are therefore not indicated. Figure 3

$171 \times 112 \mathrm{~mm}(300 \times 300 \mathrm{DPI})$ 


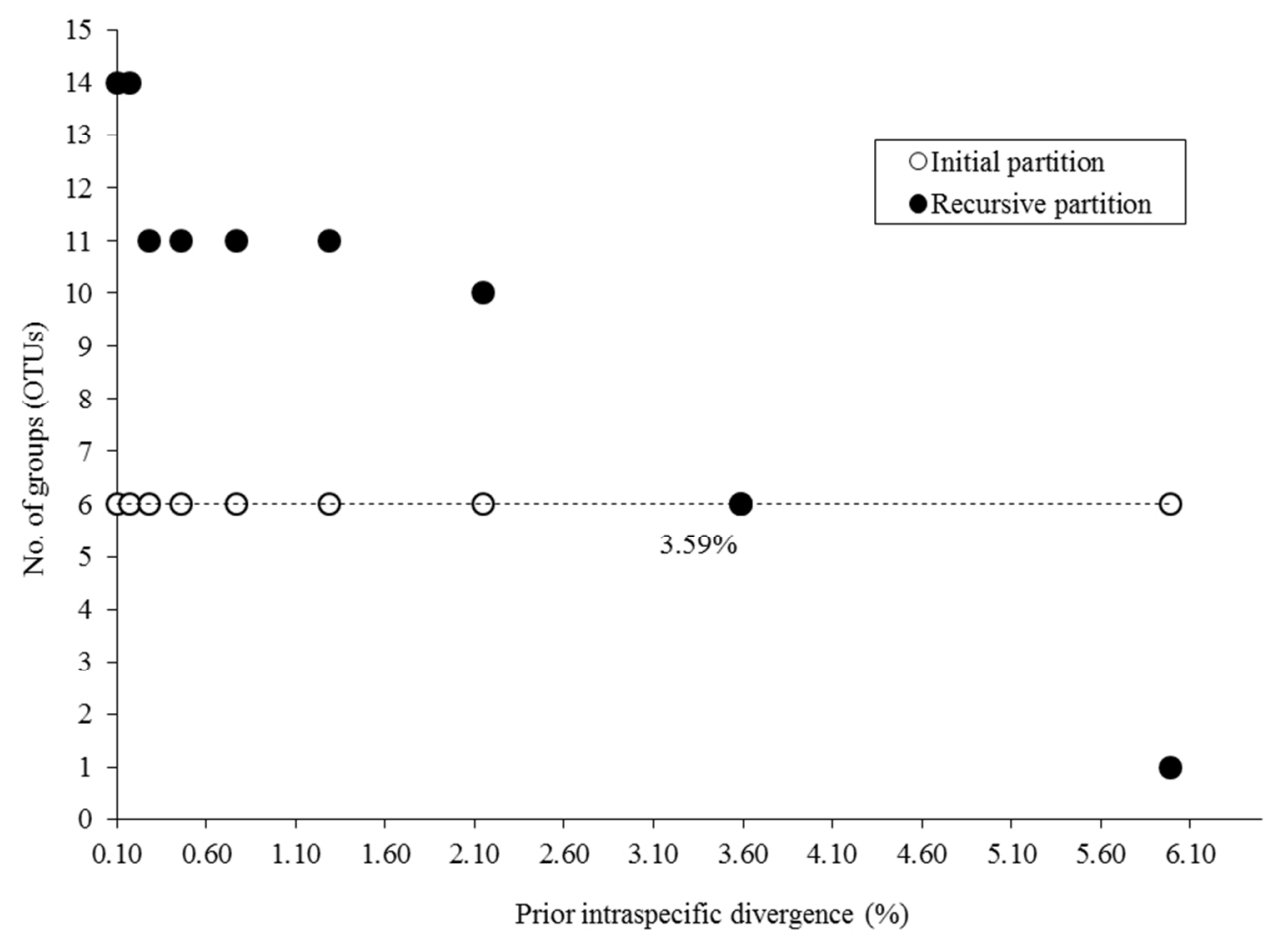

Results of the Automatic Barcode Gap Discovery (ABDG) analyses of the mtDNA COI gene using Kimura-2Parameter (K2P) distances. This analysis was for the prior intraspecific divergences for the reference dataset of six putative pangolin species based on the distance at which a barcode gap occurs.

Figure 4

$159 \times 114 \mathrm{~mm}(150 \times 150 \mathrm{DPI})$ 


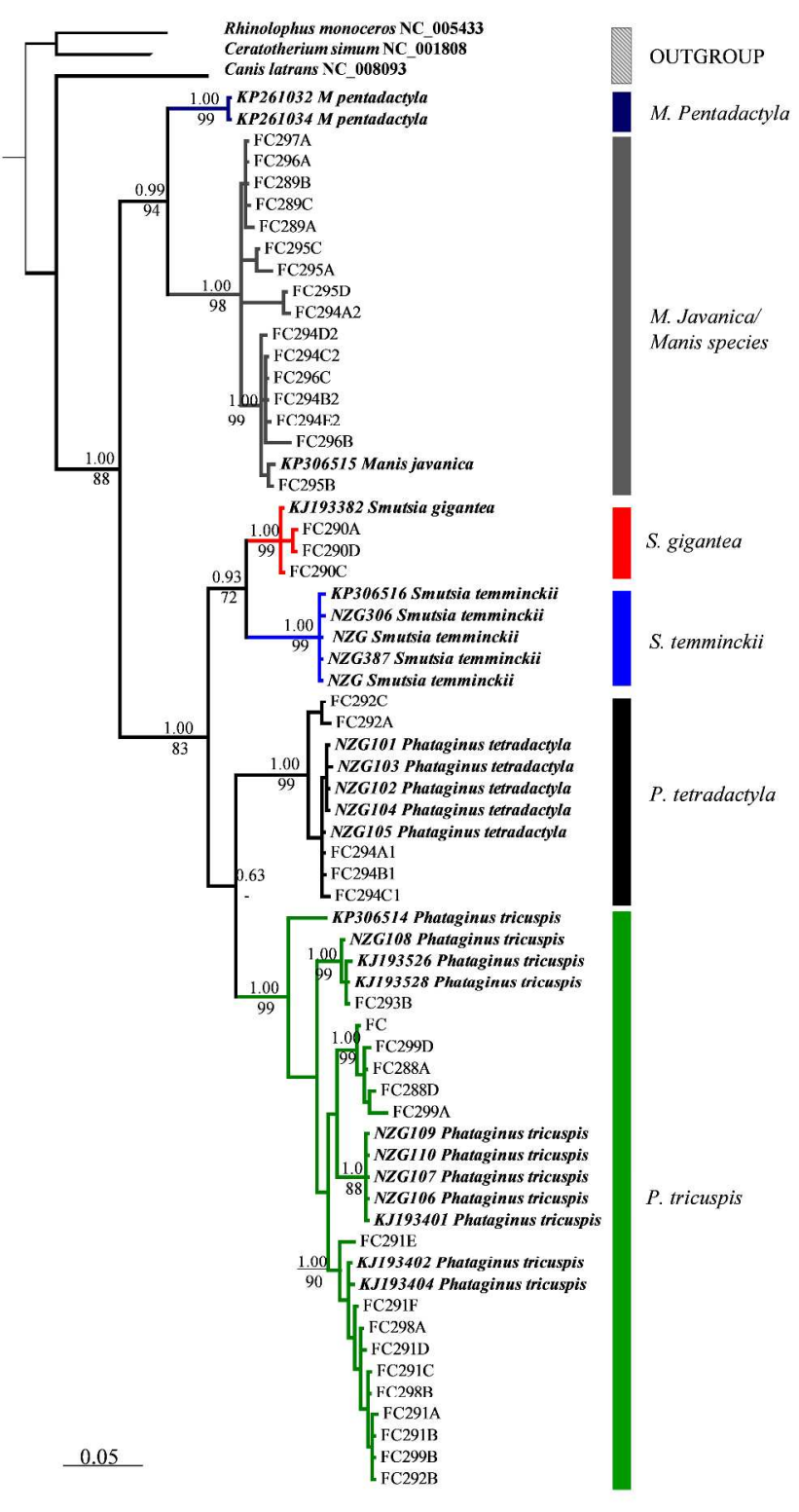

Phylogeny of the pangolin scales that were confiscated in Hong Kong in comparison to the reference species dataset (bold) based on Cyt $b$ mitochondrial DNA sequences. Neighbour-Joining bootstrap values (below) and Bayesian Inference posterior probability values (above) are indicated on the branches. Missing support values (-) indicate lack of significant BS or PP support for the clade. Clades that were not identified among the confiscated scales are indicated by blue bars.

Figure 5

$1190 \times 1587 \mathrm{~mm}(96 \times 96 \mathrm{DPI})$ 


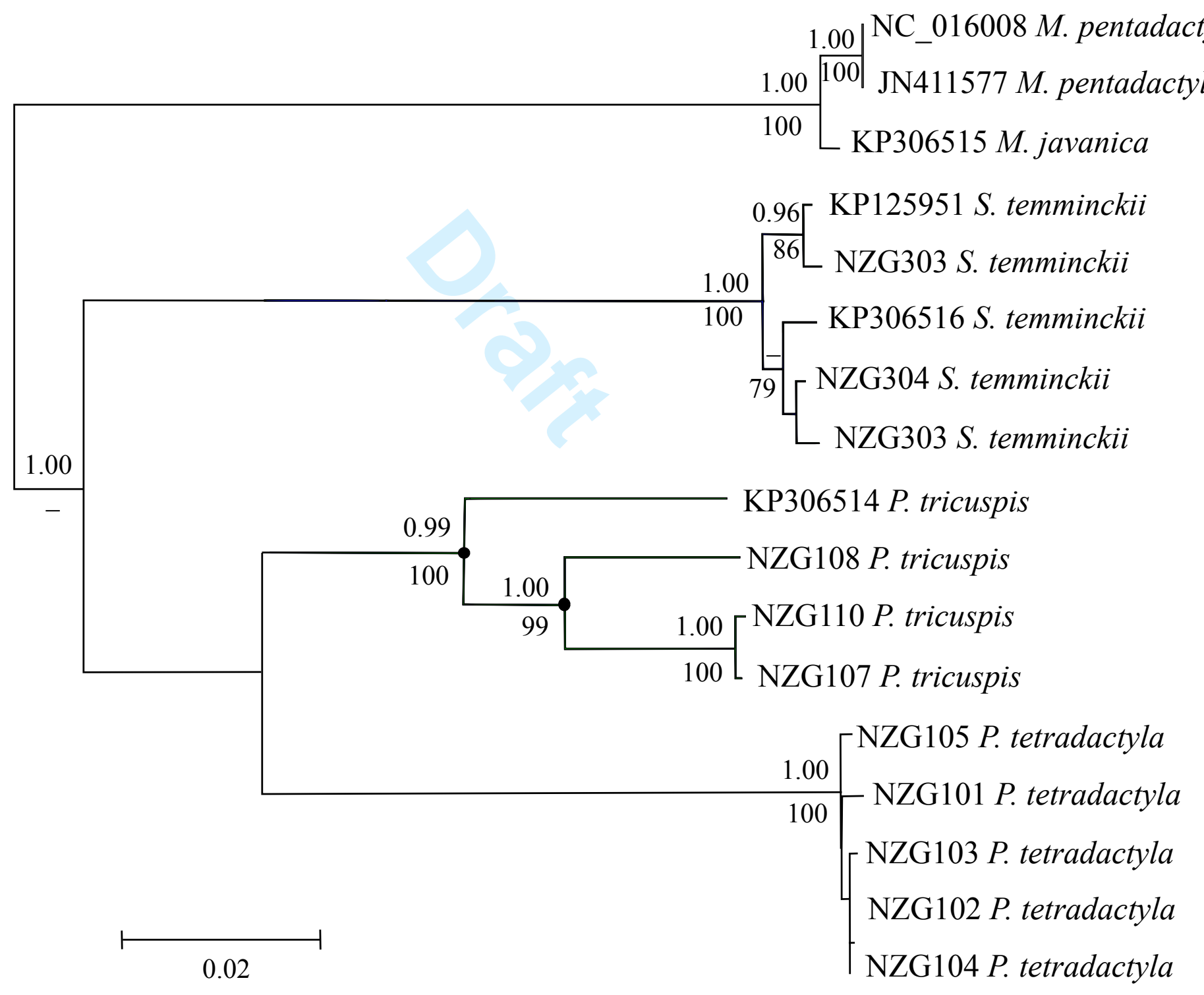

